\title{
Pore Structure Analysis of Ternary blended Concrete made with various water-binder ratios
}

\author{
D Adinarayana ${ }^{1}$, Srinivasa Rao $\mathrm{P}^{2}$, V Srinivasa Reddy ${ }^{3}$ \\ ${ }^{1}$ Research Scholar of Civil Engineering, JNTU Kakinada, Andhra Pradesh, India. \\ ${ }^{2}$ Professor, Civil Engineering Department, JNTUH, Hyderabad, Telangana, India. Email: srinivasa.pt@gmail.com \\ ${ }^{3}$ Professor, Civil Engineering Department, GRIET, Hyderabad, Telangana, India. Email:vempada@gmail.com
}

\begin{abstract}
This paper presents the chloride ion penetration and diffusion capability of ternary blended concrete made with various water cement ratios. Ternary blended concrete is made with various combinations of microsilica (MS) and fly ash (FA) for water-binder ratio of $0.55,0.45$ and 0.35 . A total of five combinations such as $5 \%$ micro-silica $+15 \%$ fly ash, $5 \%$ micro-silica $+20 \%$ fly ash, $10 \%$ micro-silica $+15 \%$ fly ash , $10 \%$ micro-silica $+20 \%$ fly ash and $0 \%$ micro-silica $+0 \%$ fly ash by weight of cement were studied for compressive strength, chloride ion permeability and pore structure analysis. It was found that $5 \%$ micro-silica $+15 \%$ fly ash showed better performance due to due to well-developed pore structure and microstructure.
\end{abstract}

\section{Introduction}

Usage of by-products formed in the industrial plants such as fly ash, micro-silica in concrete helps in improving the performance of concrete and also eases the environmental and ecological effects due to disposal and landfilling of these waste by-products. Fly ash (FA) is produced in large quantities in India of which every less amount of it is reused for various other applications. Application of fly ash in concrete not only reduced the usage of cement considerably but also enhances the properties of concrete such as reduction of heat of hydration, improvement of microstructure, development of discontinuous pore structure etc. Microsilica due to its highly reactive silica and fine size will impart strength to the concrete due to enhanced density. Microsilica and fly ash should be used in concrete in optimum quantities for improved performance in mechanical and durability aspects.

\section{Experimental Studies}

\subsection{Materials Used}

1. Cement- Ordinary Portland cement having specific gravity 2.95 and Compressive Strength at 28 days of $56.3 \mathrm{~N} / \mathrm{mm}^{2}$ is used.

2. Micro-silica (MS)- Obtained from Oriental Trexim (P) Ltd, India.
3. Fine aggregate - Natural sand conforming to Zone II and having Fineness modulus of 2.48 and Specific gravity of 2.53 is used.

4. Coarse aggregate- Aggregate having Fineness modulus of 7.17 and Specific gravity 2.70 is used.

5. Concrete mixes - Normal concrete mixes made with water-binder $(\mathrm{W} / \mathrm{B})$ ratio of 0.55 .0 .45 and 0.35 are prepared. With the similar mix proportions, ternary blended concrete mixes are prepared with several percentage mixtures of micro-silica with fly ash. Five mixtures were established based on the work done by earlier investigators such as 5\% MS $+15 \% \mathrm{FA}, 5 \% \mathrm{MS}$ $+20 \% \mathrm{FA}, 10 \% \mathrm{MS}+15 \% \mathrm{FA}, 10 \% \mathrm{MS}+20 \%$ FA and $0 \% \mathrm{MS}+0 \% \mathrm{FA}$ bwc with water-binder ratios of $0.55,0.45$ and 0.35 were prepared.

\subsection{Mix Quantities}

The following pie diagrams shows the quantities of materials required per one cubic metre of concrete mix. For $0.35 \mathrm{w} / \mathrm{c}$ ratio mix, SNF based super-plasticizer of 3.48 litres per one cubic metre of concrete mix is used. 


\subsection{W/C Ratio}

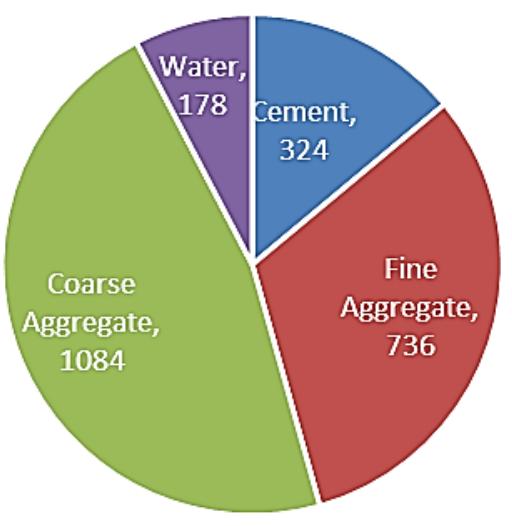

0.45 W/C Ratio

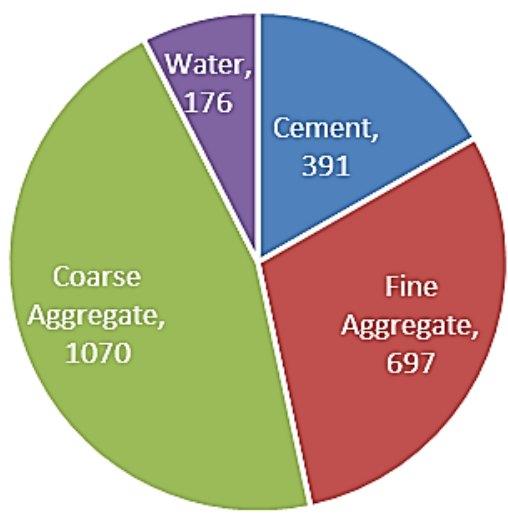

$0.35 \mathrm{~W} / \mathrm{C}$ Ratio

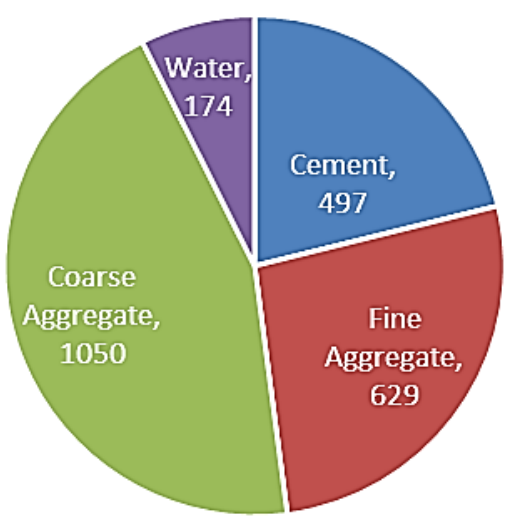

Fig. 1 - amounts of materials necessary per one metre cube of concrete mix

\subsection{Compressive Strength}

Concrete cubes of size $150 \mathrm{~mm}$ are made with combinations such as $5 \% \mathrm{MS}+15 \% \mathrm{FA}, 5 \% \mathrm{MS}+20 \% \mathrm{FA}, 10 \% \mathrm{MS}+$ $15 \% \mathrm{FA}, 10 \% \mathrm{MS}+20 \% \mathrm{FA}$ and $0 \% \mathrm{MS}+0 \% \mathrm{FA}$ bwc with water-binder ratios of $0.55,0.45$ and 0.35 and tested for compressive strength at 90 days.

\subsection{Chloride ion penetration studies}

The chloride ion passage in concrete is ruled principally via the pore arrangement and the uniformity of the concrete. Typically chlorides infiltrate in concrete by dispersion through pores. According to ASTM C1202, the Rapid chloride penetration test, is carried on concrete specimens and the total charge passing was measured which designates the opposition to chloride ion infiltration. The test decides the electrical conductance in terms of total electrical charge conceded in coulombs.

The airtightness of concrete can be signified through the flow rate /or coefficient of diffusion of chloride ions in concrete. Chloride Migration Diffusion Coefficient is evaluated from Berke's empirical formula.

Chloride Migration Diffusion Coefficient $=0.0103 * 10 \mathrm{E}-12 * \mathrm{Q}^{0.84} \mathrm{~m}^{2} / \mathrm{sec}$
Concrete Society, United Kingdom has issued guidelines to assess the quality of the concrete based on diffusion coefficients.

\section{Results and Discussions}

The table 2 below gives the compressive strengths of normal and different combinations of ternary blended concrete mixes made with various water-binder ratios.

The table 3 below gives the proportion of rise of compressive strengths of various combinations of ternary blended concrete mixtures with respect to normal concrete made with various water-binder ratios.

In all ternary blended concrete mixtures considered for examination, the compressive strength was found to be improved considerably. Especially in 5\%MS and 15\% FA the percentage increase is around $20-30 \%$ in all waterbinder ratios. It is noted that for lower water-binder ratios the synergic effect of MS and FA in concrete is quite evident. As percentage of MS and FA increased beyond $10 \%$ and $20 \%$ respectively, the improvement in compressive strength gradually reduced due to more water demand rise for the desired workability due to which strength falls gradually.

Table 2- Compressive strengths of normal and various combinations of ternary blended concrete mixes for various waterbinder ratios

\begin{tabular}{|c|c|c|c|c|}
\hline \multicolumn{2}{|c|}{ Percentage replacement } & \multicolumn{3}{|c|}{ Compressive Strength ( $\mathrm{MPa})$} \\
\hline Micro-silica & Fly Ash & $\begin{array}{c}\text { Water-binder ratio } \\
0.55\end{array}$ & $\begin{array}{c}\text { Water-binder ratio } \\
0.45\end{array}$ & $\begin{array}{c}\text { Water-binder ratio } \\
0.35\end{array}$ \\
\hline $0 \%$ & $0 \%$ & 40.44 & 49.42 & 73.24 \\
\hline $5 \%$ & $15 \%$ & 48.81 & 63.73 & 96.70 \\
\hline $5 \%$ & $20 \%$ & 46.80 & 59.84 & 90.00 \\
\hline $10 \%$ & $15 \%$ & 47.64 & 61.63 & 94.82 \\
\hline $10 \%$ & $20 \%$ & 42.00 & 51.98 & 80.12 \\
\hline
\end{tabular}


Table 3 - Percentage rise of Compressive strengths of various combinations of ternary blended concrete mixes for different water-binder ratios

\begin{tabular}{|c|c|c|c|c|}
\hline \multicolumn{2}{|c|}{ Percentage replacement } & \multicolumn{3}{|c|}{ Percentage increase in Compressive Strength } \\
\hline Micro-silica & Fly Ash & $\begin{array}{l}\text { Water-binder ratio } \\
0.55\end{array}$ & $\begin{array}{l}\text { Water-binder ratio } \\
0.45\end{array}$ & $\begin{array}{c}\text { Water-binder ratio } \\
0.35\end{array}$ \\
\hline $0 \%$ & $0 \%$ & - & - & - \\
\hline $5 \%$ & $15 \%$ & 20.76 & 28.93 & 32.03 \\
\hline $5 \%$ & $20 \%$ & 15.95 & 21.09 & 22.80 \\
\hline $10 \%$ & $15 \%$ & 17.80 & 24.70 & 29.46 \\
\hline $10 \%$ & $20 \%$ & 4.00 & 5.20 & 9.40 \\
\hline
\end{tabular}

The table below shows the total charge passed for normal and ternary blended concrete mixes as per ASTM C1202. For $5 \% \mathrm{MS}$ and $15 \% \mathrm{FA}$ combination, the passage of electric charge is very low signifying the enrichment of microstructure of ternary blended concrete. For the given water binder ratio when normal concrete and ternary blended concrete mixes are compared the permeability of ternary blended concrete reduced from 'moderate' to 'very low' which designates that ternary blended concretes are very good chloride ion resistant providing exceptional protection to rebars in concrete especially in hostile marine environments.

Table 4 - Electric Charge passed for normal and ternary blended concretes (ASTM C-1202)

\begin{tabular}{|c|c|c|c|c|c|c|c|}
\hline \multicolumn{2}{|c|}{$\begin{array}{c}\text { Percentage replacement } \\
\text { of cement }\end{array}$} & \multicolumn{2}{|c|}{$\begin{array}{c}\text { Water -binder ratio } \\
0.55\end{array}$} & \multicolumn{2}{c|}{$\begin{array}{c}\text { Water-binder ratio } \\
0.45\end{array}$} & \multicolumn{2}{c|}{$\begin{array}{c}\text { Water-binder ratio } \\
0.35\end{array}$} \\
\hline Micro-silica & Fly Ash & $\begin{array}{c}\text { Electric } \\
\text { Charge } \\
\text { Passed } \\
\text { Coulombs })\end{array}$ & $\begin{array}{c}\text { Chloride ion } \\
\text { Permeability }\end{array}$ & $\begin{array}{c}\text { Electric } \\
\text { Charge } \\
\text { Passed } \\
\text { Coulombs })\end{array}$ & $\begin{array}{l}\text { Chloride ion } \\
\text { Permeability }\end{array}$ & $\begin{array}{c}\text { Charge } \\
\text { Passed } \\
\text { Coulombs })\end{array}$ & $\begin{array}{l}\text { Chloride ion } \\
\text { Permeability }\end{array}$ \\
\hline $0 \%$ & $0 \%$ & 2419 & Moderate & 2008 & Moderate & 1022 & Low \\
\hline $5 \%$ & $15 \%$ & 367 & Very Low & 238 & Very Low & 173 & Very Low \\
\hline $5 \%$ & $20 \%$ & 1378 & Low & 1109 & Low & 876 & Very Low \\
\hline $10 \%$ & $15 \%$ & 978 & Very Low & 834 & Very Low & 562 & Very Low \\
\hline $10 \%$ & $20 \%$ & 1986 & Low & 1734 & Low & 987 & Very Low \\
\hline
\end{tabular}

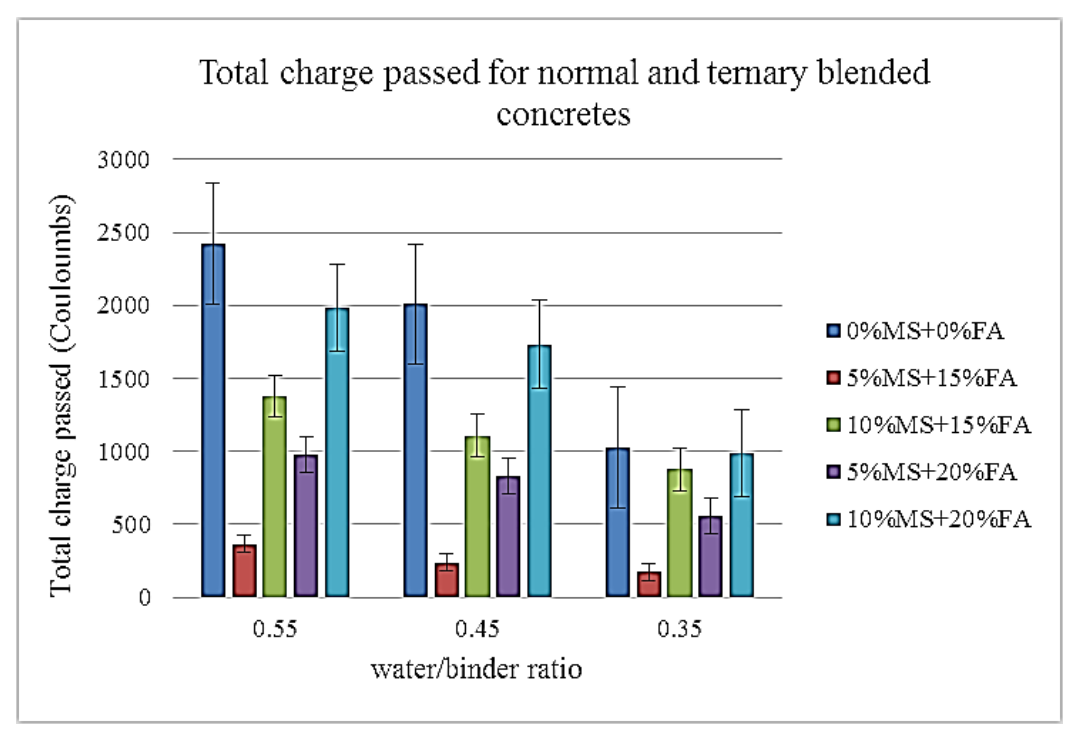

Fig. 3 - Total charge passed for various combinations of ternary blended concretes 
The table below shows chloride diffusivity of normal and ternary blended concretes.

Rapid chloride ion penetrability test performed on various combinations of ternary blended concretes for various water-binder ratios to quantify the total charge proves that the presence of micro-silica and fly ash decreases the porosity through sealing the pores exist in the concrete resulting least linking voids.

Table 5 - Chloride Diffusion Coefficients of normal and ternary blended concretes (Concrete Society of United Kingdom)

\begin{tabular}{|c|c|c|c|c|c|c|c|}
\hline \multicolumn{2}{|c|}{$\begin{array}{c}\text { Percentage } \\
\text { replacement of } \\
\text { cement }\end{array}$} & \multicolumn{2}{|c|}{$\begin{array}{c}\text { Water - binder ratio } \\
0.55\end{array}$} & \multicolumn{2}{c|}{$\begin{array}{c}\text { Water -binder ratio } \\
0.45\end{array}$} \\
\hline $\begin{array}{c}\text { Micro- } \\
\text { silica }\end{array}$ & $\begin{array}{c}\text { Fly } \\
\text { Ash }\end{array}$ & $\begin{array}{c}\text { Diffusion } \\
\text { Coefficient } \\
\text { (DC) }\end{array}$ & $\begin{array}{c}\text { Chloride } \\
\text { Permeability as }\end{array}$ & $\begin{array}{c}\text { Diffusion } \\
\text { Coefficient } \\
\text { (DC) }\end{array}$ & $\begin{array}{c}\text { Chloride } \\
\text { Permeability } \\
\text { as per }\end{array}$ & $\begin{array}{c}\text { Diffusion } \\
\text { Coefficient } \\
\text { (DC) }\end{array}$ & $\begin{array}{c}\text { Chloride } \\
\text { Permeability }\end{array}$ \\
\hline $0 \%$ & $0 \%$ & $7.17 \mathrm{E}-12$ & High & $6.12 \mathrm{E}-12$ & High & $3.47 \mathrm{E}-12$ & Medium \\
\hline $5 \%$ & $15 \%$ & $1.47 \mathrm{E}-12$ & Medium & $0.78 \mathrm{E}-12$ & Low & $0.57 \mathrm{E}-12$ & Low \\
\hline $5 \%$ & $20 \%$ & $5.58 \mathrm{E}-12$ & High & $3.24 \mathrm{E}-12$ & Medium & $3.40 \mathrm{E}-12$ & Medium \\
\hline $10 \%$ & $15 \%$ & $3.49 \mathrm{E}-12$ & Medium & $1.30 \mathrm{E}-12$ & Medium & $1.41 \mathrm{E}-12$ & Medium \\
\hline $10 \%$ & $20 \%$ & $6.31 \mathrm{E}-12$ & High & $5.63 \mathrm{E}-12$ & High & $4.58 \mathrm{E}-12$ & High \\
\hline
\end{tabular}

The table below shows the Pore diameter and Total pore volume of normal and various combinations of ternary blended concrete mixes made with various water-binder ratios.
The ternary blended concrete mixes has 'very low' chloride ion permeability which confirms its superior pore configuration.
The examination of the isotherms and hysteresis of BET shows that typical pore diameter and pore volume decreases in ternary blended concrete mixes due to dense pore structure and this observation is significant $5 \%$ microsilica and $15 \%$ fly ash concrete mixes.

Table 6 - Pore diameter and Total pore volume of normal and ternary blended concretes

\begin{tabular}{|c|c|c|c|c|c|c|c|}
\hline \multicolumn{2}{|c|}{$\begin{array}{c}\text { Percentage } \\
\text { replacement of } \\
\text { cement }\end{array}$} & \multicolumn{2}{|c|}{$\begin{array}{c}\text { Water-binder ratio } \\
0.55\end{array}$} & \multicolumn{2}{|c|}{$\begin{array}{c}\text { Water-binder ratio } \\
0.45\end{array}$} \\
\hline $\begin{array}{c}\text { Micro- } \\
\text { silica }\end{array}$ & $\begin{array}{c}\text { Fly } \\
\text { Ash }\end{array}$ & $\begin{array}{c}\text { Pore } \\
\text { diameter } \\
(\mathrm{mm})\end{array}$ & $\begin{array}{c}\text { Total pore } \\
\text { volume }(\mathrm{cc} / \mathrm{g})\end{array}$ & $\begin{array}{c}\text { Pore } \\
\text { diameter } \\
(\mathrm{mm})\end{array}$ & $\begin{array}{c}\text { Total pore } \\
\text { volume (cc/g) }\end{array}$ & $\begin{array}{c}\text { Pore } \\
\text { diameter } \\
(\mathrm{mm})\end{array}$ & $\begin{array}{c}\text { Total pore } \\
\text { volume (cc/g) }\end{array}$ \\
\hline $0 \%$ & $0 \%$ & 19.121 & 0.0161 & 5.084 & 0.0137 & 3.189 & 0.0052 \\
\hline $5 \%$ & $15 \%$ & 3.386 & 0.0071 & 3.097 & 0.0057 & 3.095 & 0.0042 \\
\hline $5 \%$ & $20 \%$ & 11.341 & 0.0113 & 4.018 & 0.0091 & 3.156 & 0.0048 \\
\hline $10 \%$ & $15 \%$ & 5.687 & 0.0083 & 3.435 & 0.0069 & 3.149 & 0.0047 \\
\hline $10 \%$ & $20 \%$ & 13.234 & 0.0143 & 4.871 & 0.0119 & 3.166 & 0.0050 \\
\hline
\end{tabular}




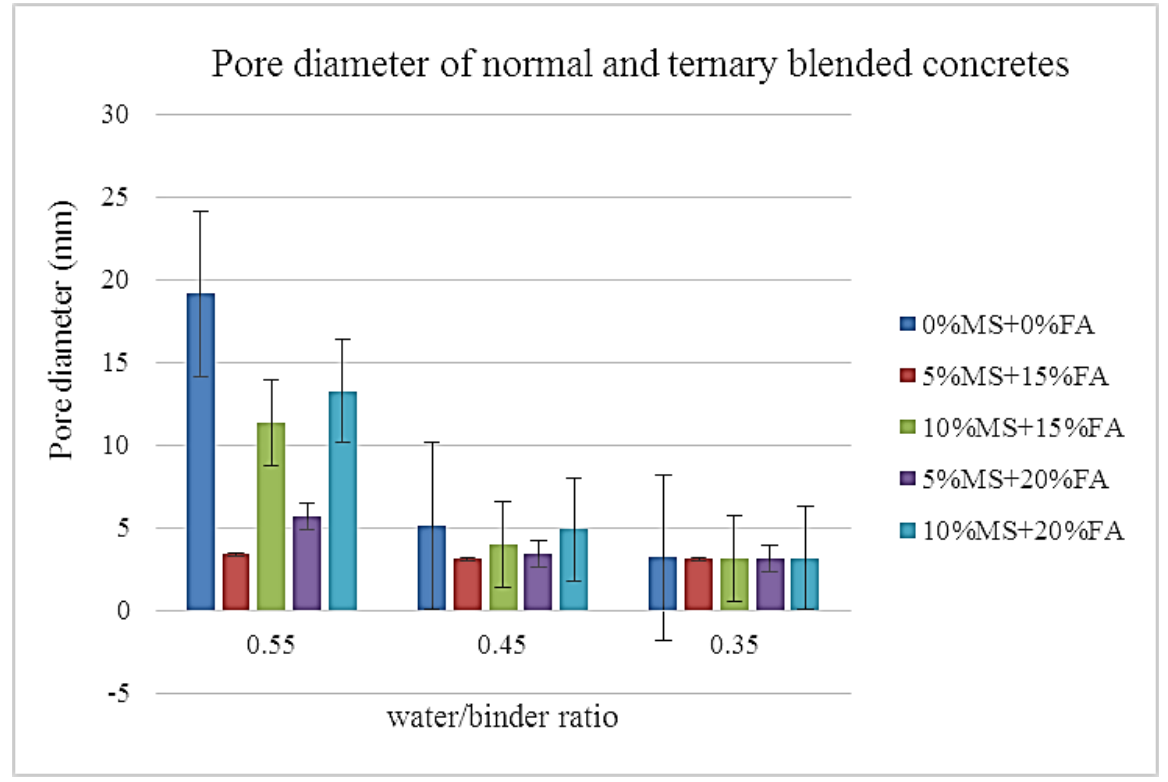

Fig. 4 - Variation of Pore diameter of ternary blended concretes

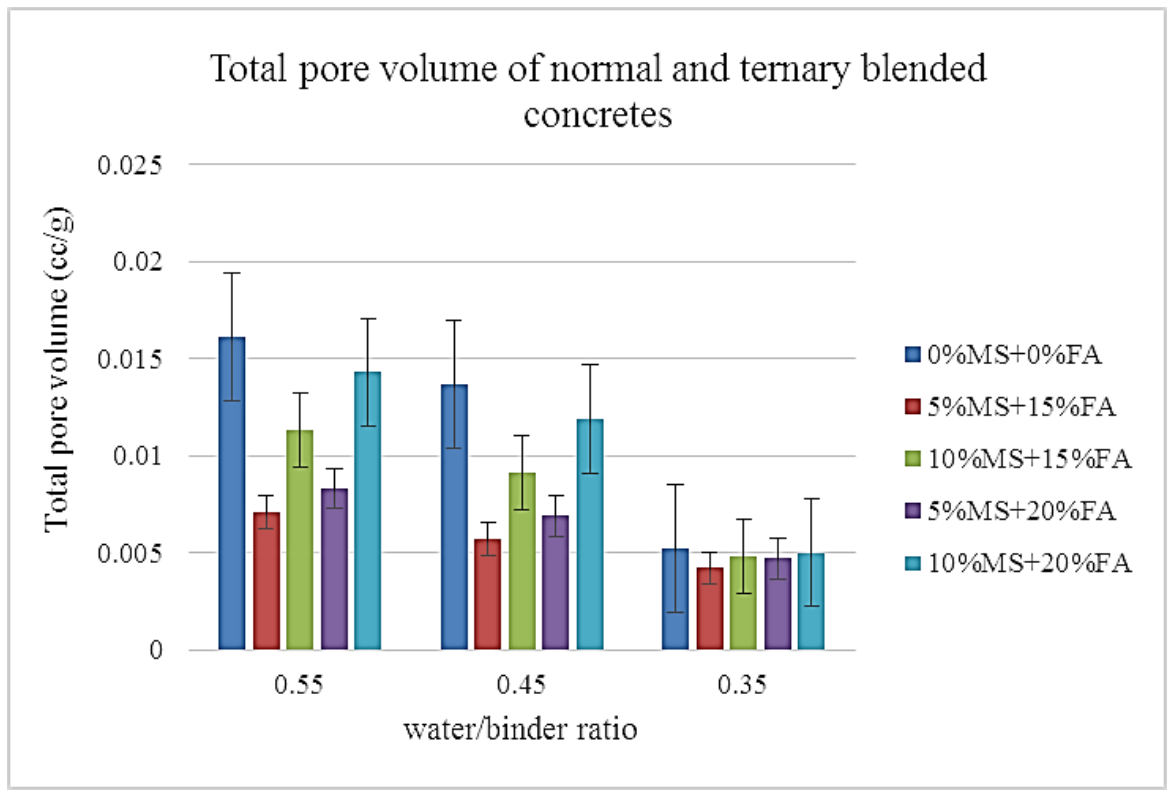

Fig. 5- Variation of total pore volume of ternary blended concretes

Pore diameter and pore volume decreases in ternary blended concrete mixes due to dense pore structure and this observation is significant $5 \%$ microsilica and $15 \%$ fly ash concrete mixes. The pore diameter of normal concrete made with W/B ratios of $0.55,0.45$ and 0.35 is $19.121 \mathrm{~mm}$, $5.084 \mathrm{~mm}$ and $3.189 \mathrm{~mm}$ respectively whereas for ternary blended concrete made with 5\%MS and $15 \% \mathrm{FA}$ and similar $\mathrm{W} / \mathrm{B}$ ratio is $3.386 \mathrm{~mm}, 3.097 \mathrm{~mm}$ and $3.095 \mathrm{~mm}$. It can be witnessed that pore diameter condensed extremely due to pozzolanic consequence (production of more calcium silicate hydrates) and filling act (filling of pores with very fine micro-silica powder).

Presence of micro-silica and fly ash decreases the porosity by sealing the pores present in the concrete resulting minimum linking voids. The ternary blended concrete mixes has very low chloride ion permeability which confirms its superior pore configuration. 


\section{Conclusions}

1. Ternary blended concrete mixes have more compressive strengths because silicates and aluminates present reacts with Calcium hydroxide produced during hydration of cement and produces $\mathrm{CSH}$ and $\mathrm{CAH}$ which adds extra strength. So ternary blended concrete mixes made with micro-silica and fly ash has amended well-developed dense and impermeable microstructure.

2. Pore diameter and pore volume decreases in ternary blended concrete mixes due to dense pore structure and this observation is significant $5 \%$ microsilica and $15 \%$ fly ash concrete mixes.

3. Inclusion of micro-silica and fly ash decreases the porosity via sealing the pores existent in the concrete resulting lowest linking voids. The ternary blended concrete mixes has 'very low' chloride ion penetrability which confirms its superior pore configuration.

4. The collaboration effect of micro-silica and fly ash is ascribed to pozzolanic act and filling act of fly ash and micro-silica respectively. Pozzolanic effect yields additional quantity of hydrates due to secondary reactions and filling effect yields compressed structure at micro and macro level.

\section{References}

1. Shweta Goyal, Maneek Kumar and B. Bhattacharjee " Potential Benefits of incorporating Fly Ash in Micro-silica concrete" "THE INDIAN CONCRETE JOURNAL" August 2008 pp. $38-46$

2. P Murthi and V Siva Kumar "Studies on the relationship between Compressive Strength and splitting tensile strength of Ternary Blended Concrete" Vol. 89, Feb 2009 IEI Journal

3. M.I. Khan, C.J. Lynsdale, P. Waldron "Porosity and strength of PFA/MS/OPC ternary blended paste" Cem. and Conc. Res. 30, 2000, pp. 1225 1229

4. Srinivasa Rao D, Sandhya Rani MN, Sarfaraz N awaz Syed and Suresh Kumar Tummala, E3S Web of Conferences 8701003 (2019)

5. Tahir Kemal Erdem, Onder Kirca "Use of binary and ternary blends in high strength concrete" Const. and Buil. Mater. 22 (2008) pg 1477 1483.

6. P Murthi and V Siva Kumar " Strength porosity relationsip for Ternary Blended Concrete" "THE INDIAN CONCRETE JOURNAL" July 2008 pp. $35-41$

7. M Anwar "Concrete properties of Ternary cementitious systems containing Fly Ash and Micro Silica” ,HBRC J. Vol. 2, No. 1 Jan 2006 pp. $67-76$
8. M.R.Jones, R.K Dhir and B.J. Magee "Concrete contacting Ternary Blended Binders: Resistance to Chloride ingress and Carbonation". Cement and Concrete Research, vol.27, No.6 (1997) Pg 825-831.

9. Lin, Y.C., Wu, F., Wang, Q.-W., Chen, D.-D., Singh, S.K. Micro- structural evolution of a Ni$\mathrm{Fe}-\mathrm{Cr}$-base superalloy during non-isothermal two-stage hot deformation (20 ) Vacuum, 151, pp. 283-293. 